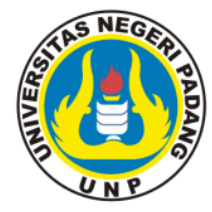

\title{
HUBUNGAN PENGUASAAN GOI DENGAN KEMAMPUAN \\ SAKUBUN MAHASISWA SEMESTER III TAHUN AJARAN 2017/2018 PROGRAM STUDI PENDIDIKAN BAHASA JEPANG UNIVERSITAS NEGERI PADANG
}

\author{
Nurul Annisac, Sitti Fatimah, Hendri Zalman \\ Program Studi Pendidikan Bahasa Jepang \\ Jurusan Bahasa dan Sastra Inggris \\ Fakultas Bahasa dan Seni \\ Universitas Negeri Padang \\ Email: nurulannisac@gmail.com
}

\begin{abstract}
Abstrak
Penelitian ini bertujuan untuk mengetahui apakah ada hubungan atau tidak ada hubungan yang signifikan antara penguasaan goi dengan kemampuan sakubun mahasiswa semester III tahun ajaran 2017/2018 Program Studi Pendidikan Bahasa Jepang Universitas Negeri Padang. Desain penelitian ini adalah desain korelasi. Populasi penelitian ini adalah mahasiswa semester III tahun ajaran 2017/2018 Program Studi Pendidikan Bahasa Jepang Universitas Negeri Padang. Jumlah total populasi dan sampel adalah 30 orang. Sampel dipilih menggunakan teknik total sampling. Pengumpulan data pada penelitian ini menggunakan 2 tes, yaitu tes objektif pilihan ganda untuk penguasaan goi dan tes esai untuk kemampuan sakubun mahasiswa. Hasil dari rumusan masalah pertama adalah skor penguasaan goi mahasiswa berada pada klasifikasi dengan pujian dengan nilai 89,76. Hasil dari rumusan masalah kedua adalah kemampuan sakubun mahasiswa berada pada klasifikasi sangat baik sekali dengan nilai 84,47 . Hasil perhitungan rumusan masalah yang ketiga adalah nilai korelasi dari dua variabel; penguasaan goi dan kemampuan sakubun adalah 0,3225. Hal ini membuktikan bahwa $\mathrm{H}_{0}$ ditolak dan $\mathrm{H}_{1}$ diterima, itu berarti ada hubungan yang signifikan antara penguasaan goi dengan kemampuan sakubun siswa.
\end{abstract}

Kata Kunci : Goi, Sakubun

The objective of the study was to find out whether there is or no significant correlation between mastery vocabulary mastery with writing ability of the third semester of Japanesse Education Program Universitas Negeri Padang students year 2017/2018. The design of this study was a correlation design. The 
populations of the study were the third semester of Japanesse Education Program Padang University students year 2017/2018. The total numbers of populations and samples were 30 students. The sample was chosen by total sampling. In collecting the data were conducted. The result of the first research question was score of students mastery of vocabulary (89.76). The results of the second research question was the mean score of students writing ability (84.47). The result of statistical calculation of the third research question was the value of correlation of two variables; vocabulary mastery with writing ability was 0.30861 . It means that $\mathrm{H}_{0}$ was rejected and $\mathrm{H}_{1}$ was accepted, it is mean there is significance correlation between student's vocabulary mastery with their writing ability.

Keyword : vocabulary, writing

\section{A. PENDAHULUAN}

Belajar bahasa Jepang sama dengan belajar bahasa lainnya, karena dalam bahasa Jepang siswa juga mempelajari empat kemampuan berbahasa yaitu kemampuan menyimak (kiku nouryoku), kemampuan berbicara (hanasu nouryoku), kemampuan membaca (yomu nouryoku), dan kemampuan menulis (kaku nouryoku). Meskipun dalam pembelajaran keterampilan berbahasa ini dipilah - pilah menjadi empat keterampilan, namun pada hakikatnya, keempat keterampilan tersebut terintergrasi, khusunya dalam proses komunikasi. Asano dalam Sudjianto (2009:97) menyatakan bahwa tujuan akhir pengajaran bahasa Jepang adalah agar pembelajar mampu mengkomunikasikan ide atau gagasannya dengan menggunakan bahasa Jepang baik secara lisan maupun tulisan.

Menurut Tarigan (1982:3) "menulis merupakan suatu keterampilan berbahasa yang dipergunakan untuk berkomunikasi secara langsung, tetapi tidak secara tatap muka dengan orang lain". Dengan menulis, seseorang dapat mengungkapkan ide, gagasan, pendapat dan pemikiran-pemikirannya ke dalam bentuk cerita fiksi maupun nonfiksi. Mengembangkan kemampuan menulis bukanlah hal yang mudah, karena dalam menulis diperlukan suatu proses mengolah data dan pikiran untuk dituangkan dalam bentuk kata-kata dan kalimat agar mudah dipahami oleh pembaca.

Sutedi (2009:2) mengatakan keterampilan menulis dalam bahasa Jepang dapat digolongkan ke dalam tiga macam, yaitu : menulis huruf (Kana dan Kanji), menulis kalimat (Bunsaku), menulis cerita/karangan (Sakubun). Sakubun sering dianggap paling sulit oleh pembelajar. Pembelajar dituntut untuk mengerahkan semua keterampilan berbahasa Jepangnya ketika akan menyampaikan suatu ide atau gagasannya ke dalam bentuk tulisan.

Menurut Alwasilah (dalam Sutedi, 2009:2) kemampuan sakubun ditunjang oleh dua kemampuan pokok, yaitu kemampuan linguistik dan kemampuan 
komposisi. Kemampuan linguistik adalah kemampuan dalam menguasai bahasa Jepang, mulai dari penguasaan huruf (Kana dan Kanji), kosakata, pola kalimat, ungkapan dan aturan gramatika yang berlaku didalam bahasa Jepang. Adapun yang dimaksud dengan kemampuan komposisi adalah kemampuan menyajikan cerita atau isi karangan berdasarkan alur tertentu yang sesuai dengan budaya dan kebiasaan penutur bahasa Jepang.

Dapat disimpulkan dari aspek-aspek penunjang kemampuan sakubun di atas, kosakata termasuk kedalam aspek kemampuan linguistik yang mendasar. Sudjianto (2009:97) mengemukakan bahwa kosakata (goi) adalah keseluruhan kata berkenaan dengan suatu bahasa atau bidang tertentu yang ada di dalamya. Goi juga merupakan alat utama yang harus dimiliki seseorang, sebab goi berfungsi untuk membentuk kalimat serta mengutarakan isi pikiran dan perasaan baik secara lisan maupun tulisan. Bagi pembelajar bahasa Jepang, kurangnya penguasaan kosakata menjadi kendala yang sangat besar dan dapat menghambat pembelajar dalam menguasai keempat aspek keterampilan berbahasa salah satunya sakubun.

Sebagai salah satu komposisi dalam sakubun, maka bisa diasumsikan bahwa goi berkorelasi dengan sakubun. Semakin bagus penguasaan goi seseorang, maka semakin bagus pula kemampuan sakubunnya. Sesuai dengan hasil penelitian Nova Yulia (2009) dalam tesisnya yang berjudul "Pengaruh Penguasaan Kosakata Bahasa Jepang Terhadap Kemampuan Mengarang :Studi Deskriptif Terhadap Mahasiswa Semester III Jurusan Pendidikan Bahasa Jepang Universitas Pendidikan Indonesia Tahun Ajaran 2007/2008, yang menemukan bahwa adanya hubungan penguasaan kosakata terhadap kemampuan mengarang pada mahasiswa semester III Jurusan Pendidikan Bahasa Jepang Universitas Pendidikan Indonesia tahun ajaran 2007/2008. Untuk membuktikan asumsi di atas, maka penulis merasa perlu untuk mengadakan penelitian tentang "Hubungan Penguasaan Goi dengan Kemampuan Sakubun Mahasiswa Semester III Tahun Ajaran 2017/2018 Program Studi Pendidikan Bahasa Jepang Universitas Negeri Padang”

\section{B. METODE PENELITIAN}

Jenis penelitian ini adalah penelitian kuantitatif dengan metode korelasional. Populasi dalam penelitian ini adalah mahasiswa semester III tahun masuk 2016 Program Studi Pendidikan Bahasa Jepang Universitas Negeri Padang dengan jumlah mahasiswa 30 orang.Dikarenakan mahasiswa semester III tahun masuk 2016 Program Studi Pendidikan Bahasa Jepang Universitas Negeri Padang yang terdaftar pada tahun ajaran 2017/2018 hanya satu kelas yaitu berjumlah 30 orang, maka sampel penelitian ini ditarik dengan menggunakan teknik total sampling.

Instrumen penelitian ini berupa tes yang digunakan untuk mengumpulkan data penguasaan goi dan kemampuan sakubun siswa mahasiswa semester III 
tahun ajaran 2017/2018 program studi pendidikan bahasa jepang universitas negeri padang tahun sesuai dengan indikator yang dinilai. Indikator untuk penguasaan goi adalah mampu menentukan arti kata, menggunakan kosakata yang sesuai dengan kalimat dan menentukan lawan kata. Sedangkan indikator kemampuan sakubun adalah mampu menggunakan dan menuliskan kosakata mengenai kegiatan sehari-hari, mampu menggunakan pola kalimat yang benar mengenai kegiatan sehari-hari dan mampu menuliskan paragraf berdasarkan rangkaian gambar. Untuk validitas tes penguasaan goi adalah validitas butir, sedangkan untuk tes kemampuan sakubun digunakan validitas isi. Pengujian reliabilitas tes penguasaan goi dihitung dengan rumus $\mathrm{KR} 21$, dengan $\mathrm{r}_{\text {hitung }}$ 0,8466, sehingga instrumen dinyatakan reliabel.

Adapun teknik pengumpulan data dalam penelitian ini sebagai berikut. Tes dilakukan dua kali, pertama tes penguasaan goi dan kedua tes kemampuan sakubun. Untuk tes penguasaan goi dan tes kemampuan sakubun, langkah pertama, memberikan soal tes kepada siswa. Kedua, memeriksa hasil tes siswa. Ketiga, memberikan skor terhadap hasil tes siswa. Dan keempat mengubah skor menjadi nilai.

Setelah data terkumpul, tahap selanjutnya adalah menganalisis data. Langkah-langkah yang dilakukan dalam menganalisis data tersebut adalah sebagai berikut. Pertama, mengklasifikasikan nilai penguasaan goi dan kemampuan sakubun mahasiswa berdasarkan peraturan akademik Universitas Negeri yaitu nilain85 s.d. 100 dengan pujian, 80 s.d. 84 sangat baik sekali, 75 s.d. 79 baik sekali, 70 s.d. 74 baik, 65 s.d. 69 cukup baik, 55 s.d. 59 cukup, 50 s.d. 54 kurang cukup, 40 s.d. 49 kuran dan $\leq 39$ gagal. Kedua, Menghitung penguasaan goi dan kemampuan skubun mahasiswa per indikator. Ketiga, Menentukan nilai rata-rata hitung penguasaan goi per indikator. Keempat, Mengklasifikasikan penguasaan goi dan sakubun mahasiswa per indikator berdasarkan peraturan akademik Universitas Negeri yaitu nilain85 s.d. 100 dengan pujian, 80 s.d. 84 sangat baik sekali, 75 s.d. 79 baik sekali, 70 s.d. 74 baik, 65 s.d. 69 cukup baik, 55 s.d. 59 cukup, 50 s.d. 54 kurang cukup, 40 s.d. 49 kuran dan $\leq 39$ gagal . Kelima, Mengorelasikan kedua variabel yaitu penguasaan goi dan kemampuan sakubun. Keenam, Pengujian hipotesis korelasi penguasaan goi dengan kemampuan sakubun. Ketujuh, membahas hasil analisis data dan membuat kesimpulan.

\section{HASIL DAN PEMBAHASAN}

\section{Temuan Penelitian}

Data dalam penelitian ini adalah skor tes penguasaan goi dan skor kemampuan sakubun mahasiswa semester III tahun ajaran 2017/2018 Prodi Pendidikan Bahasa Jepang Universitas Negeri Padang yang terdaftar pada tahun ajaran 2017/2018 yang berjumlah 30 orang. Tes penguasaan goi berupa tes objektif pilihan ganda dan mencocokkan. Tipe soal pilihan ganda dengan empat 
alternatif pilihan jawaban A, B, C, dan D. Soal tes pilihan ganda yang diberikan berjumlah 20 butir. Tipe soal mencocokkan yaitu menentukan lawan kata yang tepat. Soal tes mencocokkan yang diberikan berjumlah 10 butir. Soal yang diujikan meliputi tiga indikator penilaian yaitu: (1) mampu menentukan arti kata, (2) menggunakan kosakata yang sesuai dengan kalimat, dan (3) menentukan lawan kata. Untuk indikator mampu menentukan arti kata, mahasiswa harus mampu mengartikan suatu kosakata dari bahasa Indonesia ke bahasa Jepang. Untuk indikator menggunakan kosakata yang sesuai dengan kalimat, mahasiswa harus mampu menentukan kosakata mana yang paling cocok untuk melengkapi kalimat yang diberikan. Untuk indikator menentukan lawan kata, mahasiswa harus mampu mencocokkan suatu kata dengan lawan katanya secara tepat.

Data kemampuan sakubun mahasiswa diperoleh melalui tes yang diberikan kepada 30 orang mahasiswa. Tes tersebut berupa tes esai. Soal yang diujikan meliputi tiga indikator penilaian yaitu: (1)Mampu menggunakan dan menuliskan kosakata mengenai kegiatan sehari-hari, (2)Mampu menggunakan pola kalimat mengenai kegiatan sehari-hari, dan (3)Mampu menulis secara detail berdasarkan gambar mengenai kegiatan sehari-hari. Untuk indikator kosakata (goi), mahasiswa harus mampu menggunakan kosakata mengenai kegiatan sehari-hari. Untuk indikator pola kalimat (bunkei), mahasiswa harus mampu menggunakan pola kalimat mengenai kegiatan sehari-hari. Untuk indikator isi, mahasiswa harus mampu menulis secara detail sesuai topik mengenai watashi no ichinichi yang ada pada gambar.

Temuan penelitian hubungan penguasaan goi dengan kemampuan sakubun mahasiswa semester III tahun ajaran 2017/2018 Programdang Studi Pendidikan Bahasa Jepang Universitas Negeri Padang adalah sebagai berikut. Pertama, penguasaan goi Mahasiswa semester III Tahun Ajaran 2017/2018 Prodi Pendidikan Bahasa Jepang Universitas Negeri Padang adalah 89,76. Secara umum dapat dikelompokkan menjadi empat klasifikasi. Pertama, 25 orang mahasiswa $(83,33 \%)$ berada pada klasifikasi dengan pujian. Kedua, 1 orang mahasiswa $(3,33 \%)$ berada pada klasifikasi sangat baik sekali. Ketiga, 3 orang mahasiswa $(10 \%)$ berada pada klasifikasi baik sekali. Keempat, 1 orang mahasiswa $(3,33 \%)$ berada pada klasifikasi baik.

Kedua, kemampuan sakubun mahasiswa semester III Tahun Ajaran 2017/2018 Prodi Pendidikan Bahasa Jepang Universitas Negeri Padang adalah 84,47. Secara umum dapat dikelompokkan menjadi lima klasifikasi. Pertama, 19 orang mahasiswa $(63,33 \%)$ berada pada klasifikasi dengan pujian. Kedua, 1 orang mahasiswa $(3,33 \%)$ berada pada klasifikasi sangat baik sekali. Ketiga, 8 orang mahasiswa $(26,67 \%)$ berada pada klasifikasi baik sekali. Keempat, 1 orang mahasiswa $(3,33 \%)$ berada pada klasifikasi cukup baik. Kelima, 1 mahasiswa $(3,33 \%)$ berada pada klasifikasi lebih dari cukup.

Ketiga, terdapat hubungan yang signifikan antara penguasaan goi dengan kemampuan sakubun mahasiswa semester III Program Studi Pendidikan Bahasa Jepang Universitas Negeri Padang pada taraf signifikan 95\% dengan derajat 
kebebasan n-2 (30-2=28). Dengan demikian, $\mathrm{H}_{0}$ ditolak dan $\mathrm{H}_{1}$ diterima, karena hasil pengujian membuktikan bahwa hasil pengkorelasian antara variabel penguasaan bunkei dengan kemampuan hanasu koto siswa kelas X MIA 7 SMA Negeri 10 Padang diperoleh $r_{\text {hitung }}\left(r_{x y}\right)$ adalah 0,3225. Setelah $r_{\text {hitung }}$ diperoleh, selanjutnya dianalisis dengan menggunakan rumus uji t. Hal ini dilakukan untuk melihat apakah korelasi berarti pada taraf signifikan tertentu. Setelah dianalisis, diperoleh nilai $t_{\text {hitung }}$ sebesar 1,803 lebih besar dari $t_{\text {tabel }}$ dengan derajat kebebasan n-2 dan taraf signifikan $95 \%$ yaitu sebesar 1,70.

\section{Pembahasan}

Berdasarkan deskripsi data dan analisis data menunjukkan secara keseluruhan penguasaan goi dan kemampuan sakubun mahasiswa semester III tahun ajaran 2017/2018 Prodi Pendidikan Bahasa Jepang Universitas Negeri Padang. Penguasaan goi pada rata-rata 89,76 sedangkan kemampuan sakubun dengan rata-rata 84,47 .

Dalam penelitian ini diketahui pada penguasaan goi memiliki 3 indikator penilaian. Pertama, menentukan arti kata dan diperoleh rata-rata nilai 88,2. Kedua, mengunakan kosakata yang sesuai dengan kalimat dengan rata-rata nilai 86,23. Ketiga, menentukan lawan kata dengan rata-rata nilai 97,33. Dari ketiga indikator tersebut terlihat jika pada indikator 3 adalah yang paling dikuasai oleh mahasiswa dalam penguasaan goi mahasiswa semester III tahun ajaran 2017/2018 Prodi Pendidikan Bahasa Jepang Universitas Negeri Padang. Dan paling rendah adalah pada indikator 2 yaitu menggunakan kosakata yang sesuai dengan kalimat. Hal ini menunjukkan bahwa mahasiswa lebih sulit untuk menggunakan kosakata pada sebuah kalimat yang telah ada daripada mengartikan kosakata atau menentukan lawan kata.

Dalam penelitian ini juga diketahui kemampuan sakubun memiliki 3 indikator penilaian. Pertama, menggunakan dan menuliskan kosakata mengenai kegiatan sehari-hari ( $g o i$ ) dengan rata-rata nilai 80,83. Kedua, menggunakan pola kalimat yang benar mengenai kegiatan sehari-hari (bunkei) dengan rata-rata nilai 73,33. Ketiga,menulis paragraf berdasarkan rangkaian gambar (isi) dengan ratarata nilai 95,83. Dari ketiga indikator tersebut terlihat indikator yang paling dikuasai oleh mahasiswa adalah indikator isi. Hal ini dikarenakan dalam tes kemampuan sakubun mahasiswa telah dibantu dengan adanya gambar urutan kegiatan. Untuk indikator yang terendah yang dikuasai mahasiswa adalah pada indikator 2 yaitu menggunakan pola kalimat yang benar. Hal ini menunjukkan bahwa mahasiswa masih terkendala dalam menggunakan pola kalimat yang benar dan sesuai. Beberapa kesalahan misalnya mahasiswa menggunakan pola kalimat bentuk lampau pada karangan kegiatan sehari-hari. 
Jika dilihat dari rata-rata nilai penguasaan goi dengan rata-rata nilai kemampuan sakubun pada indikator goi memiliki nilai yang sama-sama tinggi. Ini membuktikan jika goi berkontribusi dalam kemampuan sakubun seperti yang telah di jelaskan Alwasilah (dalam Sutedi, 2009:2) yang menyatakan bahwa kemampuan mengarang bahasa Jepang secara garis besarnya ditunjang oleh dua kemampuan pokok, yaitu kemampuan linguistik (pola kalimat dan kosakata) dan kemampuan komposisi (isi karangan). Selain itu indikator-indikator lainnya juga mempunyai peran yang sama besarnya dalam kemampuan sakubun.

Hubungan penguasaan goi dengan kemampuan sakubun yang dihitung dengan product moment dan dieroleh 0,3225 yang menunjukkan tingkat korelasi

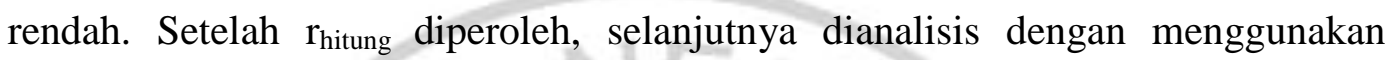
rumus uji t. Hal ini dilakukan untuk melihat apakah korelasi berarti pada taraf signifikan tertentu. Setelah dianalisis, diperoleh nilai $t_{\text {hitung }}$ sebesar 1,803 lebih besar dari $t_{\text {tabel }}$ dengan derajat kebebasan $n-2$ dan taraf signifikan $95 \%$ yaitu sebesar 1,70. Dari hasil pengkorelasian tersebut disimpulkan bahwa terdapat korelasi yang signifikan antara penguasaan goi dengan kemampuan sakubun mahasiswa semester III tahun ajaran 2017/2018 Prodi Pendidikan Bahasa Jepang Universitas Negeri Padang.

\section{KESIMPULAN DAN SARAN}

\section{Kesimpulan}

Berdasarkan deskripsi data, analisis data, dan pembahasan mengenai penguasaan goi dengan kemampuan sakubun mahasiswa semester III tahun ajaran 2017/2018 prodi pendidikan bahasa Jepang Universitas Negeri Padang, secara khusus dapat disimpulkan tiga hal sebagai berikut. Pertama, penguasaan goi Mahasiswa semester III Tahun Ajaran 2017/2018 Prodi Pendidikan Bahasa Jepang Universitas Negeri Padang secara umum dapat dikelompokkan menjadi empat klasifikasi. Pertama, 25 orang mahasiswa (83,33\%) berada pada klasifikasi dengan pujian. Kedua, 1 orang mahasiswa $(3,33 \%)$ berada pada klasifikasi sangat baik sekali. Ketiga, 3 orang mahasiswa (10\%) berada pada klasifikasi baik sekali. Keempat, 1 orang mahasiswa $(3,33 \%)$ berada pada klasifikasi baik.

Kedua, kemampuan sakubun mahasiswa semester III Tahun Ajaran 2017/2018 Prodi Pendidikan Bahasa Jepang Universitas Negeri Padang secara umum dapat dikelompokkan menjadi lima klasifikasi. Pertama, 19 orang mahasiswa $(63,33 \%)$ berada pada klasifikasi dengan pujian. Kedua, 1 orang mahasiswa $(3,33 \%)$ berada pada klasifikasi sangat baik sekali. Ketiga, 6 orang mahasiswa (20\%) berada pada klasifikasi baik sekali. Keempat, 3 orang mahasiswa (10\%) berada pada klasifikasi cukup baik. Kelima, 1 mahasiswa $(3,33 \%)$ berada pada klasifikasi lebih dari cukup.

Ketiga, terdapat hubungan yang signifikan antara kebiasaan hubungan penguasaan goi dengan kemampuan sakubun mahasiswa semester III tahun ajaran 
2017/2018 prodi pendidikan bahasa Jepang Universitas Negeri Padang pada taraf $95 \%$ dengan derajat kebebasan $\mathrm{n}-2(30-2=28)$. Dengan demikian, $\mathrm{H}_{0}$ ditolak dan $\mathrm{H}_{1}$ diterima karena hasil pengujian membuktikan bahwa $t_{\text {hitung }}$ lebih besar dari $\mathrm{t}_{\text {tabel, }}$ yaitu 1,803>1,70.

\section{Saran}

Diharapkan dengan adanya penelitian ini dapat menambah referensi yang berhubungan dengan menambah wawasan tentang hubungan penguasaan goi dengan kemampuan sakubun pembelajar bahasa Jepang. Selain itu, diharapkan juga bagi pembelajar bahasa Jepang untuk meningkatkan motivasi agar terus menggali kemampuan dalam berbagai bidang.

Dan diharapkan untuk pengajar bahasa Jepang dengan adanya penelitian dapat menjadi acuan penilaian yang lebih dan mampu memberi gambaran tentang hubungan penguasaan goi dengan kemampuan sakubun.

\section{DAFTAR PUSTAKA}

Sutedi, Dedi. 2009. Penelitian Pendidikan Bahasa Jepang. Bandung: Humaniora. Sudjianto \& Ahmad Dahidi. .2009.Pengantar Linguistik Bahasa Jepang. Jakarta : Kesaint Blanc

Tarigan, H. G. 1982. Menulis sebagai Suatu Keterampilan Berbahasa. Bandung: Angkasa

Yulia, Nova. 2009. Tesis Pengaruh Penguasaan Kosakata Bahasa Jepang Terhadap Kemampuan Mengarang :Studi Deskriptif Terhadap Mahasiswa Semester III Jurusan Pendidikan Bahasa Jepang Universitas Pendidikan Indonesia Tahun Ajaran 2007/2008. Bandung 